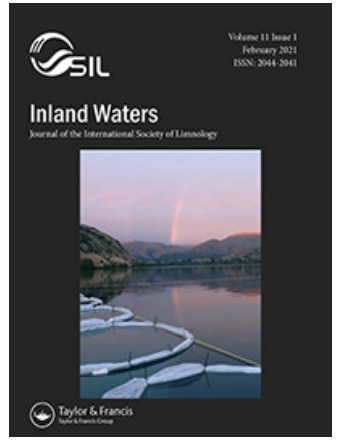

Inland Waters

ISSN: (Print) (Online) Journal homepage: https://www.tandfonline.com/loi/tinw20

\title{
On the role of local depth and latitude on surface warming heterogeneity in the Laurentian Great Lakes
}

\section{Elisa Calamita, Sebastiano Piccolroaz, Bruno Majone \& Marco Toffolon}

To cite this article: Elisa Calamita, Sebastiano Piccolroaz, Bruno Majone \& Marco Toffolon (2021): On the role of local depth and latitude on surface warming heterogeneity in the Laurentian Great Lakes, Inland Waters, DOI: 10.1080/20442041.2021.1873698

To link to this article: https://doi.org/10.1080/20442041.2021.1873698

View supplementary material ¿

\section{Published online: 31 Mar 2021.}

Submit your article to this journal $₫$

Q View related articles $\sqsubset$

View Crossmark data $₫$ 


\title{
On the role of local depth and latitude on surface warming heterogeneity in the Laurentian Great Lakes
}

\author{
Elisa Calamita (1), ${ }^{\mathrm{a}, \mathrm{b}}$ Sebastiano Piccolroaz (1), ${ }^{\mathrm{a}, \mathrm{c}}$ Bruno Majone (10, ${ }^{\mathrm{a}}$ and Marco Toffolon (1) ${ }^{\mathrm{a}}$ \\ ${ }^{a}$ Department of Civil, Environmental and Mechanical Engineering, University of Trento, Trento, Italy; ${ }^{\mathrm{b}}$ Institute of Biogeochemistry and \\ Pollutant Dynamics, ETH Zürich, Zürich, Switzerland; 'Physics of Aquatic Systems Laboratory, Ecole Polytechnique Fédérale de Lausanne, \\ Lausanne, Switzerland
}

\begin{abstract}
Lake surface water temperature (LSWT) responds rapidly to changes in climatic variables. This response is heterogeneous in space and its spatial distribution is primarily influenced by lake bathymetry and latitude. Such heterogeneity is not captured by one-dimensional water temperature models, which can accurately predict only the average LSWT. We performed a spatially distributed application of the hybrid physically based/data-driven model air2water to predict the LSWT variability in the 5 Laurentian Great Lakes and to deepen our understanding of the role of local depth and latitude in shaping this heterogeneous response. Daily remotely sensed LSWT data were used to calibrate and validate the model during 1995-2018, and additional simulations considering a synthetic warmer climate scenario in which air temperature was increased by $2{ }^{\circ} \mathrm{C}$ were run to assess the inter- and intra-lake differences in LSWT warming rates. The model reproduces the observed spatial distribution of LSWT with an average root mean squared error of $1.2{ }^{\circ} \mathrm{C}$ and suggests that, under the warmer scenario, the LSWT of the 5 lakes could increase heterogeneously, with the deepest zones showing the maximum warming rates. Summer stratification lengthening is expected to increase with higher local depth; this behaviour attenuates with increasing latitude, whereas the LSWT warming is essentially dependent on the local depth, irrespective of latitude. We highlight the importance of accounting for LSWT spatial heterogeneity to adequately assess the thermal response of the Great Lakes to a warming climate.
\end{abstract}

ARTICLE HISTORY

Received 21 April 2020

Accepted 25 December 2020

\section{KEYWORDS}

air2water; climate change; lake surface water temperature; limnology; reanalysis; remote sensing

\section{Introduction}

By reflecting changes in the climate as well changes in their drainage catchment, lakes are recognized as sentinels of climate change (Williamson et al. 2009a). In this respect, lake surface water temperature (LSWT) is considered a highly informative indicator because of its rapid and direct response to changes in climatic forcing (Adrian et al. 2009, Williamson et al. 2009b). LSWT is indeed rapidly warming worldwide, in some cases reaching higher warming rates than the surrounding air temperature (Austin and Colman 2007, Schneider and Hook 2010). However, such warming has different magnitudes at different latitudes and different geographical regions, with more thermally responsive lakes generally located in the temperate region (Piccolroaz et al. 2020) and some hotspots for climate sensitivity identified in the Laurentian Great Lakes region and in Northern Europe (O'Reilly et al. 2015). LSWT response to external changes is also spatially variable within a lake, with significant intra-lake variability mainly dependent on lake bathymetry (Mason et al. 2016, Woolway and Merchant 2018, Matsumoto et al. 2019, Zhong et al. 2019, Toffolon et al. 2020).

During the last decades, satellite technology largely contributed to the availability of spatially distributed LSWT observations worldwide. Remotely sensed multi-spectra images have been available since the 1980s with progressively higher spatial and temporal resolution (Giardino et al. 2013, Pareeth et al. 2016, Irani Rahaghi et al. 2019). Maps of LSWT provide detailed information about the spatial heterogeneity of the thermal dynamics in lakes and additional evidence that many lakes are warming, including those located in ungauged regions not previously monitored (Schneider and Hook 2010). At the same time, the increased availability of remotely sensed observations fostered research on intra-lake and inter-lake LSWT heterogeneity, aimed at improving the understanding of the spatial and temporal patterns in lake warming and identifying key drivers controlling the process 
(Steissberg et al. 2005, Oesch et al. 2008, Schneider et al. 2009, Toffolon et al. 2014, Zhang et al. 2014, Piccolroaz et al. 2015, Bouffard et al. 2018, Lieberherr and Wunderle 2018, Prats et al. 2018).

Some of these studies used the 5 Laurentian Great Lakes (USA-Canada) as a case study (Trumpickas et al. 2009, 2015, Piccolroaz et al. 2015, Mason et al. 2016, Zhong et al. 2016, Kravtsov et al. 2018, Zhong et al. 2019, Toffolon et al. 2020) because of their wide variation in bathymetry and latitude, and thus their inter- and intra-lake surface water temperature variability. In addition, a consistent historical observational dataset of LSWT for the Laurentian Great Lakes is available for the past decades and is continuously updated (Hunter et al. 2015). Although the Laurentian Great Lakes have been identified as a world hotspot for LSWT warming rates (O’Reilly et al. 2015), the leading mechanisms controlling such warming are still under debate (Kravtsov et al. 2018, Sugiyama et al. 2018). For example, Austin and Colman (2007) claimed that the ice-albedo feedback is one of the major causes of accelerated lake warming, and recently Winslow et al. (2017) suggested that this effect may only be important for large lakes such as the Laurentian Great Lakes. However, other studies argued that the compensation between ice-albedo feedback is counterbalanced by the insulation due to the ice cover, limiting LSWT warming (Vavrus et al. 1996, Gerbush et al. 2008, Zhong et al. 2016, Ye et al. 2019).

The understanding of lake warming is complicated because LSWT is predominantly controlled by thermal stratification magnitude and timing (Piccolroaz et al. 2015), which in turn depend on basin morphometric characteristics including the local depth of the water column (Gorham and Boyce 1989, Butcher et al. 2015, Kraemer et al. 2015, Magee and $\mathrm{Wu}$ 2017). Thus, the bathymetry of the lake exerts a strong control on the surface heat balance, resulting in horizontally heterogeneous LSWT values and contributing to the major differences existing between pelagic and benthic ecosystems (Beaulieu et al. 2013, Vašek et al. 2016, Binding et al. 2018).

Together with bathymetry, latitude has also been identified as a key factor for LSWT warming rates (Carmack et al. 2014, Zhong et al. 2016, 2019). In recent global studies, the deepest lakes located at high latitudes were found to be subjected to the highest warming rates in summer (Woolway and Merchant 2017), and the mean annual LSWT sensitivity to changes in air temperature was found to be markedly different across climate regions (Piccolroaz et al. 2020). However, the extent to which the depth-latitude relationship is expected to affect the inter-lake LSWT warming has received little attention to date.
In this study we investigated the spatial dynamics of LSWT and its feedback with stratification in the 5 Laurentian Great Lakes, focusing on the effects of local depth and latitude. The analysis was performed using a lumped model applied in a spatially distributed manner. We used the air2water model (Piccolroaz et al. 2013, 2016, Toffolon et al. 2014), which allows LSWT predictions using air temperature (AT) as the sole input in meteorological forcing and has been applied successfully in many studies worldwide (Wilcox 2010, Piccolroaz et al. 2013, Toffolon et al. 2014, Piccolroaz et al. 2015, Javaheri et al. 2016, Piccolroaz 2016, Schmid and Köster 2016, Wood et al. 2016, Czernecki and Ptak 2018, Piccolroaz et al. 2018, Piccolroaz and Toffolon 2018, Prats and Danis 2019, Flaim et al. 2020, Heddam et al. 2020, Piccolroaz et al. 2020, Zhu et al. 2020). However, while previous applications were aimed at reproducing lakeaveraged LSWT, here we applied for the first time the model locally to capture LSWT spatial variability. In this way, we also tested the possibility of using a simple and parsimonious model to indirectly (i.e., by looking at local model performance) identify where and to what extent local LSWT is affected by processes other than air-water heat exchange and stratification (e.g., lakewide circulation, coastal upwelling and downwelling, river inflows), which would require solving a more complex 3-dimensional model. In addition, to better understand and quantify the heterogeneity in the LSWT response to a warmer climate, we applied the air2water model considering a synthetic, uniform scenario of AT. In particular, we note how the analysis of the spatial distribution of the model parameters together with the evaluation of the response of different lake zones to a constant AT warming could elucidate how different regions within lakes are expected to respond to air temperature changes throughout the 21st century. Moreover, the analysis of the results allowed us to detect the role of depth and latitude in shaping the heterogeneity in LSWT warming rates and stratification dynamics.

In summary, the objectives of this study are to (1) test whether a simple model such as air2water, applied in a distributed manner, can reproduce the spatial variability of LSWT; (2) investigate the spatial variability of the thermal response of the Laurentian Great Lakes to a warmer synthetic scenario; and (3) analyse how local depth and latitude affect the duration of summer stratification and LSWT warming.

\section{Materials and methods}

\section{The Laurentian Great Lakes}

Located in North America, the Laurentian Great Lakes are glacial lakes holding nearly $20 \%$ of the world supply 
of surface freshwater. Their drainage watershed covers $>777000 \mathrm{~km}^{2}$ and lies mainly in a humid continental climate undergoing large seasonal temperature variations. Each lake spreads over a different latitude range (Fig. 1a), and therefore the AT seasonality changes from lake to lake. Lake Superior is the northernmost lake $\left(40.4^{\circ}-49.0^{\circ} \mathrm{N}\right)$ and thus experiences a colder AT than the other lakes (based on lake-averaged AT taken from ERA-Interim Reanalyses dataset; discussed later). At this latitude, AT averages between -12 and $17{ }^{\circ} \mathrm{C}$ during the year. Lake Michigan, Lake Huron, and Lake Ontario are located at lower latitudes (41.6$46.2^{\circ} \mathrm{N}, 43.0-46.3^{\circ} \mathrm{N}$, and $43.1-44.3^{\circ} \mathrm{N}$, respectively), with an average annual AT range between -8 and $22{ }^{\circ} \mathrm{C}$. Finally, Lake Erie is the southernmost (41.3$43.0^{\circ} \mathrm{N}$ ) of the Laurentian Great Lakes, and AT is typically warmer, ranging between -5 and $24{ }^{\circ} \mathrm{C}$.

While the 5 lakes share a common glacial origin, their morphology and bathymetry differ considerably (see Fig. 1a). Lake Superior is largest in terms of volume and surface area and also deepest, with a maximum depth of $\sim 406 \mathrm{~m}$ and average depth of $\sim 147 \mathrm{~m}$. Lake Michigan is the second largest by volume, with an average depth of $\sim 85 \mathrm{~m}$. Lake Michigan covers a wide range of different latitudes because of its elongated shape and north-south orientation, with the deepest part $(282 \mathrm{~m})$ located in the middle of the lake. Lake Huron has an average depth of $59 \mathrm{~m}$, and its maximum depth is $228 \mathrm{~m}$. Lake Ontario and Lake Erie have a comparable surface area, which is smaller than the others, but Ontario has an average depth of $\sim 86 \mathrm{~m}$ and a maximum depth of $245 \mathrm{~m}$ while Erie is the shallowest of the 5 lakes, with a maximum depth of $64 \mathrm{~m}$ and an average depth of $\sim 19 \mathrm{~m}$. Lake Erie is also characterized by a relatively narrow range of depth variability (additional characteristics of the 5 lakes summarized in Table 1).

\section{Available data}

LSWT maps provided by the National Oceanic and Atmospheric Administration (NOAA) Great Lakes Coast Watch Program's Great Lakes Surface Environment Analysis version 2 (GLSEA2; http://www.glerl. noaa.gov) were used in this study to calibrate and validate the air2water model. These satellite products are publicly available and are calibrated with in situ limnological buoy observations. LSWT maps are distributed with a $1.25 \mathrm{~km}$ grid resolution over a domain covering the whole Laurentian Great Lakes region. GLSEA2 maps do not present gaps in the time window considered in this study and are in overall good agreement with LSWT measured by offshore buoys managed by NDBC network (Leshkevich et al. 1996, Schwab et al. 1999, Zhong et al. 2019).
In this study we used the satellite GLSEA2 maps from January 1995 until December 2018 (24 yr) at a daily resolution. Spatial resolution of LSWT maps was reduced by averaging $10 \times 10$ cells and thus obtaining upscale maps at a spatial resolution of $12.5 \mathrm{~km} \times 12.5 \mathrm{~km}$ (see Fig. 1b). Upscaling was introduced to filter out local small-scale variability in LSWT that could not be captured by the air2water conceptualization (discussed later). Analogously, boundary cells (i.e., upscaled cells containing $<70 \%$ of the original high-resolution lake cells) were removed to avoid possible errors in LSWT estimates in the coastal regions due to the presence of land portions. The bathymetric map for each of the 5 lakes was derived at the same spatial resolution as that of the LSWT maps (Fig. 1a) by interpolating bathymetric contour lines provided by NOAA (https://www. ngdc.noaa.gov/mgg/greatlakes/).

Daily AT data covering the same time window selected for LSWT satellite data were obtained from the ERA-Interim Reanalyses dataset, provided by the European Centre for Medium-Range Weather Forecasts (ECMWF: http://apps.ecmwf.int/datasets/data/interimfull-daily/). The ERA-Interim AT maps have a spatial resolution of 0.5 latitudinal and longitudinal degree, corresponding to about $55 \mathrm{~km}$. To avoid possible spurious effects on the spatial distribution of AT over the single lakes generated by the coarse resolution of the reanalysis data, we averaged the values of each lake map to obtain one single daily AT series for each lake (identified by rectangular areas in Supplemental Fig. S1). However, for the sake of comparison, we also tested the methodology using the original spatial distribution of AT, obtaining fully coherent results with no substantial differences.

\section{Water temperature modelling}

Among the different versions of the air2water family of models (Piccolroaz et al. 2013), we selected the version with 4 parameters. The performances of different conceptualizations of the model have been previously tested (Piccolroaz et al. 2013, Toffolon et al. 2014, Piccolroaz 2016), and we adopted the version presenting the lowest number of parameters to keep the analysis as simple as possible. This 4-parameter version of the model reads as follows:

$$
\frac{d T_{w}}{d t}=\frac{1}{\delta}\left\{a_{1}+a_{2} T_{a}-a_{3} T_{w}\right\},
$$

where $T_{w}$ represents LSWT $\left({ }^{\circ} \mathrm{C}\right), T_{a}$ is air temperature $\left({ }^{\circ} \mathrm{C}\right), t$ is time $(\mathrm{d}), d t$ is the time-step (chosen as $\left.1 \mathrm{~d}\right), \delta$ is the dimensionless volume of the lake surface layer participating to the heat exchanges estimated as $\delta=\exp \left[-\left(T_{w}-T_{r}\right) / a_{4}\right]$ when $T_{w}>T_{r}$ (where $T_{r}$ is the deep water reference temperature, which can be 

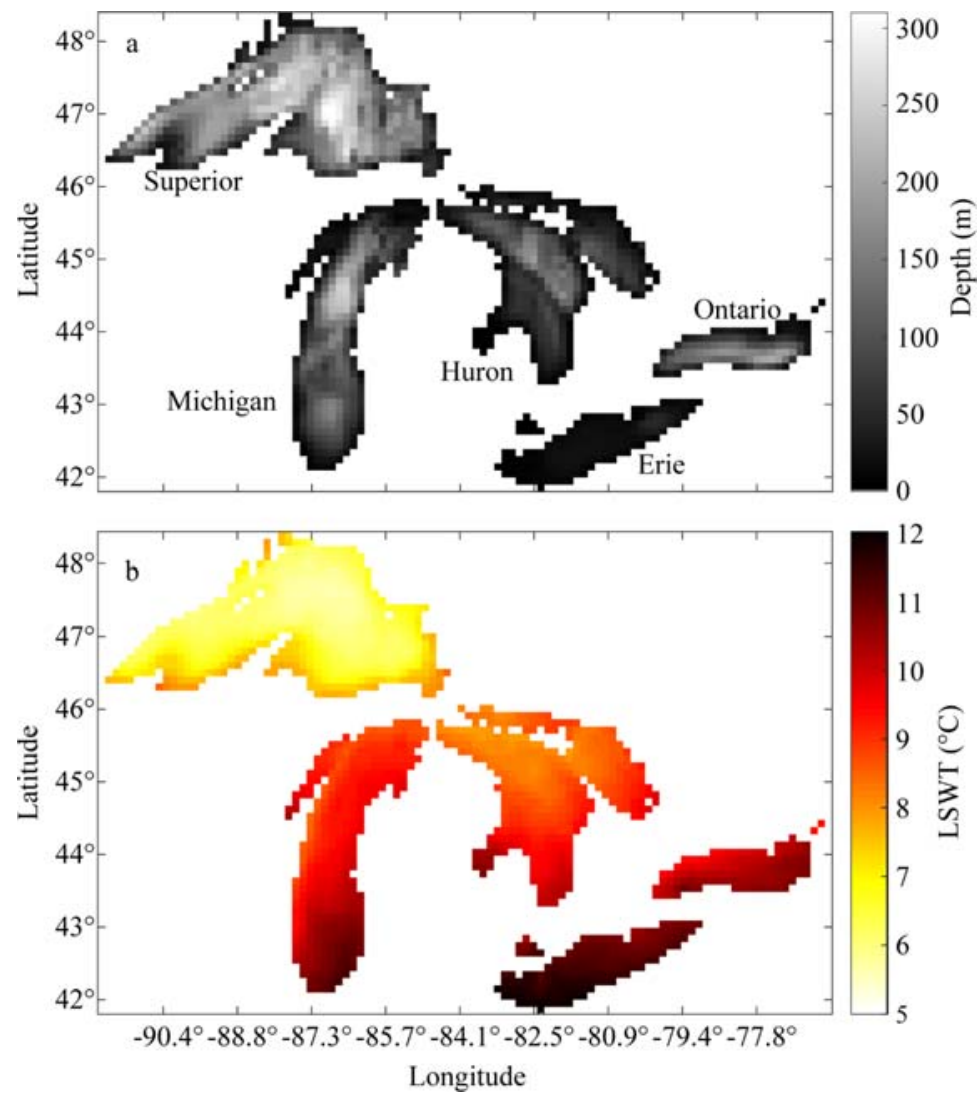

Figure 1. (a) Bathymetric map of the 5 Laurentian Great Lakes with a spatial resolution of $12.5 \mathrm{~km} \times 12.5 \mathrm{~km}$ and (b) spatial variability of the observed time averaged daily LSWT with the same spatial resolution.

assumed equal to $4{ }^{\circ} \mathrm{C}$ for dimictic lakes; Hutchinson and Loffler 1956, Boyce et al. 1989), otherwise $\delta=1$, including periods of ice cover; and $a_{1}, a_{2}, a_{3}, a_{4}$, are the parameters of the model to be calibrated. A lower bound of $0{ }^{\circ} \mathrm{C}$ is imposed to $T_{w}$ for physical reasons. Equation 1 was integrated at a daily scale using the Crank-Nicolson numerical method (Griffiths and Smith 2006). We calibrated the model by using the particle swarm optimization algorithm (Kennedy et al. 2010) and considering the root mean square error (RMSE) between simulated and observed daily LSWT as an objective function. Together with the mean error (ME), these metrics are commonly used in limnological studies because they provide a dimensional estimate of the error, which is crucial to understand the implications of introduced error (Stepanenko et al. 2010, Thiery et al. 2014).

Table 1. Main characteristics of the 5 Laurentian Great Lakes.

\begin{tabular}{lcccccc}
\hline & $\begin{array}{c}\text { Surf. } \\
\text { area } \\
\left(\mathrm{km}^{2}\right)\end{array}$ & $\begin{array}{c}\text { Volume } \\
\left(\mathrm{km}^{3}\right)\end{array}$ & $\begin{array}{c}\text { Elevation } \\
(\mathrm{m} \text { a.s.l. })\end{array}$ & $\begin{array}{c}\text { Average } \\
\text { depth }(\mathrm{m})\end{array}$ & $\begin{array}{c}\text { Max } \\
\text { depth } \\
(\mathrm{m})\end{array}$ & $\begin{array}{c}\mathrm{N}^{\circ} \\
\text { cells } \\
(-)\end{array}$ \\
\hline Superior & 82000 & 12000 & 183 & 147 & 406 & 576 \\
Michigan & 58000 & 4900 & 176 & 85 & 282 & 361 \\
Huron & 60000 & 3500 & 176 & 59 & 228 & 393 \\
Erie & 25700 & 480 & 174 & 19 & 64 & 163 \\
Ontario & 19000 & 1640 & 75 & 86 & 245 & 117 \\
\hline
\end{tabular}

The 4 parameters $a_{1}-a_{4}$ encapsulate the main thermophysical properties of the waterbody. Particularly, $a_{2}\left(\mathrm{~d}^{-1}\right)$ accounts for the processes that depend (directly or indirectly) on AT; $a_{3}\left(\mathrm{~d}^{-1}\right)$ describes the response of LSWT, hence providing an estimate of the time scale of its adaptation to changes in AT; $a_{4}\left({ }^{\circ} \mathrm{C}\right)$ is the scale of water temperature that controls thermal stratification; and $a_{1}\left({ }^{\circ} \mathrm{C} \mathrm{d}^{-1}\right)$ is a factor that includes all residual effects (Toffolon et al. 2014).

The model was applied in each cell of the Laurentian Great Lakes independently, thus obtaining different sets of model parameters calibrated for each element. As meteorological forcing input, each cell used the daily lake-averaged AT time series (discussed in previous section). The model was calibrated using 17 of the 24 years of available LSWT data; the remaining 7 years of LSWT data were used to validate the model. We included in the calibration period the 5 coldest and the 5 warmest years of our data series to let the model be informed by the extreme conditions of AT. This classification was performed by first calculating the lake-averaged LSWT annual means and then aggregating the results over the 5 lakes to obtain a reference annual LSWT value for the overall Laurentian Great Lakes system. From this spatially and annually averaged data series, we extracted the 5 

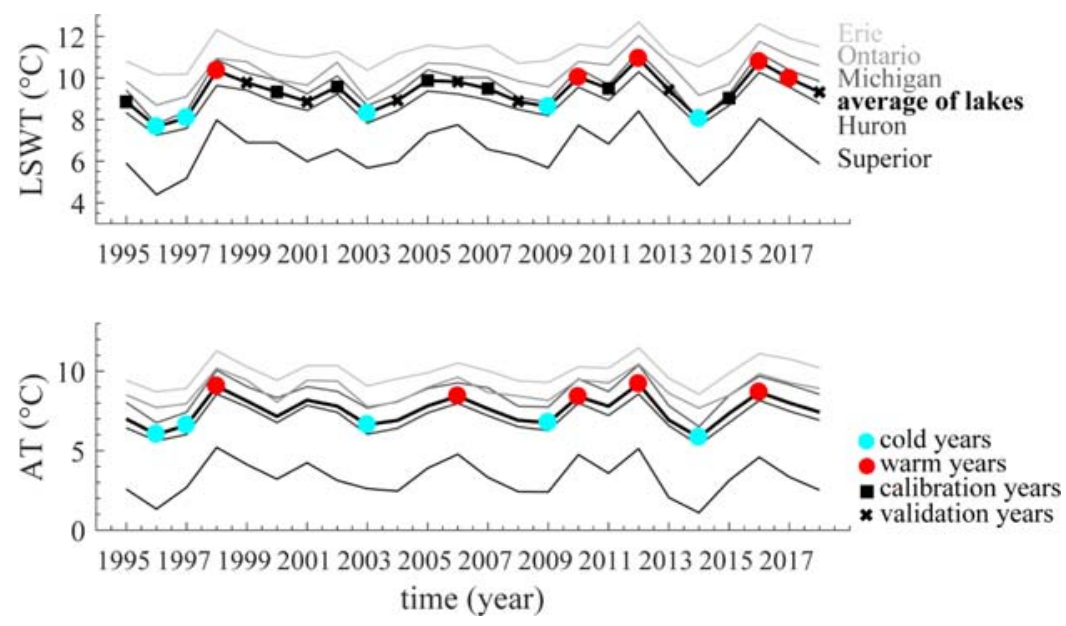

Figure 2. (a) Mean annual lake-averaged surface water temperature (LSWT) for all 5 Laurentian Great Lakes and (b) mean annual air temperature (AT) over the 5 lakes during 1995-2018. Red and cyan dots represent the 5 coldest and warmest years respectively. Black $\mathrm{x}=$ years used to validate the model in this study; other years were used for model calibration (filled black squares).

coldest and warmest years. Among the remaining 14 years we selected the 7 years for the validation period by alternating calibration and validation years (Fig. 2).

The air2water model was then used to assess how the Laurentian Great Lakes LSWT responds to a synthetic scenario of AT warming to quantify the differences in LSWT warming given the same AT increase for each cell of each lake. To this end, we considered a synthetic scenario where AT was uniformly increased by $2{ }^{\circ} \mathrm{C}$, a value coherent with the range observed in the last decades between the coldest and warmest years (Toffolon et al. 2020). Simulations were run for the same 24-year period but using the modified (i.e., warmer) AT time series, keeping the parameters obtained during calibration procedure.

\section{Analysis and metrics}

To assess the intra-lake LSWT heterogeneity, the lake cells were divided into 3 bathymetric classes depending on their local depth: shallow, deep, and very deep. We classified lake cells by considering the statistical distribution of cells depth relative to each lake separately. The 10th percentile of the distribution was considered as the threshold separating the shallow and the deep cells classes while the 90th percentile was assumed as the threshold separating the deep and very deep cells classes.

Table 2. Threshold values for the identification of the depth classes for the 5 Laurentian Great Lakes.

\begin{tabular}{lcc}
\hline & $\begin{array}{c}\text { 10th percentile of local depth } \\
\text { distribution }(\mathrm{m})\end{array}$ & $\begin{array}{c}\text { 90th percentile of local depth } \\
\text { distribution }(\mathrm{m})\end{array}$ \\
\hline Superior & 48 & 238 \\
Michigan & 17 & 162 \\
Huron & 12 & 118 \\
Erie & 7 & 25 \\
Ontario & 22 & 165 \\
\hline
\end{tabular}

The characteristics of the 3 cell classes for the 5 lakes were summarized (Table 2). We stress that, according to the above definition, the bathymetric classes refer to different depth ranges depending on the lake. This approach allowed us to distinguish different lake zones in all 5 lakes (also in the shallower Erie), contributing to a richer description of intra-lake thermal variability. The alternative approach of comparing cells considering their absolute depth was also conducted, but the results are not shown here because they added no additional elements to the analyses presented in this work.

To study the effects of the warmer scenario on the inter-lake heterogeneity, we evaluated the climatological years for the actual and warmer scenario (by averaging for each day of the year all LSWT values for that same day; e.g., Toffolon et al. 2020) and then quantified the LSWT response to changes in AT by calculating the difference in temperature $(\Delta T)$ between the two on a daily basis and for each cell of the 5 lakes. Then, we identified the maximum $\Delta \mathrm{T}(\max \Delta \mathrm{T})$ for each cell of the lakes, along with the day of the year (DOY) when it occurred. We also calculated the monthly average of daily differences to obtain the mean monthly $\Delta \mathrm{T}$ for each cell. The monthly $\Delta \mathrm{T}$ time series were then averaged within each depth class (for each lake separately) to obtain one mean monthly $\Delta \mathrm{T}$ value per depth class and per lake.

Finally, we estimated the duration of summer stratification (DSS) for each lake cell. Specifically, we calculated the period in which the water column is stratified in the current conditions and in the warming scenario by using the corresponding climatological years of LSWT. All 5 Laurentian Great Lakes are dimictic; that is, LSWT crosses the temperature of maximum density of $4{ }^{\circ} \mathrm{C}$ two times per year: in spring when lakes stratify and in early fall when they start mixing before 

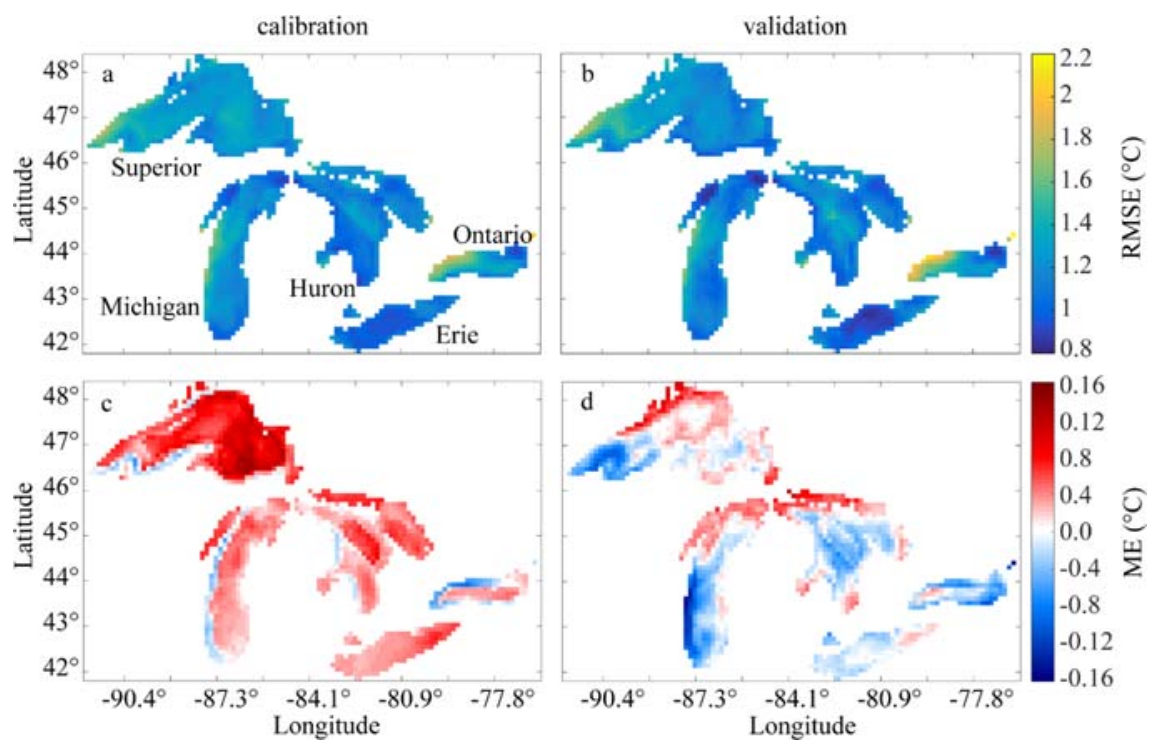

Figure 3. Spatial distribution of the root mean squared error (RMSE) and mean error (ME) between the daily simulated and observed lake surface water temperature (LSWT). The RMSE and ME values are presented for both $(a, c)$ calibration and (b, d) validation periods.

the inverse stratification in winter. Hence, for sake of simplicity, the summer stratification period was defined as the period when LSWT is $>4{ }^{\circ} \mathrm{C}$ (McCormick 1990). To assess the effect of a warming climate on stratification, we calculated the difference in duration of summer stratification ( $\triangle D S S)$ between the DSS in the warmer scenario and in the current conditions for each cell of the lakes.

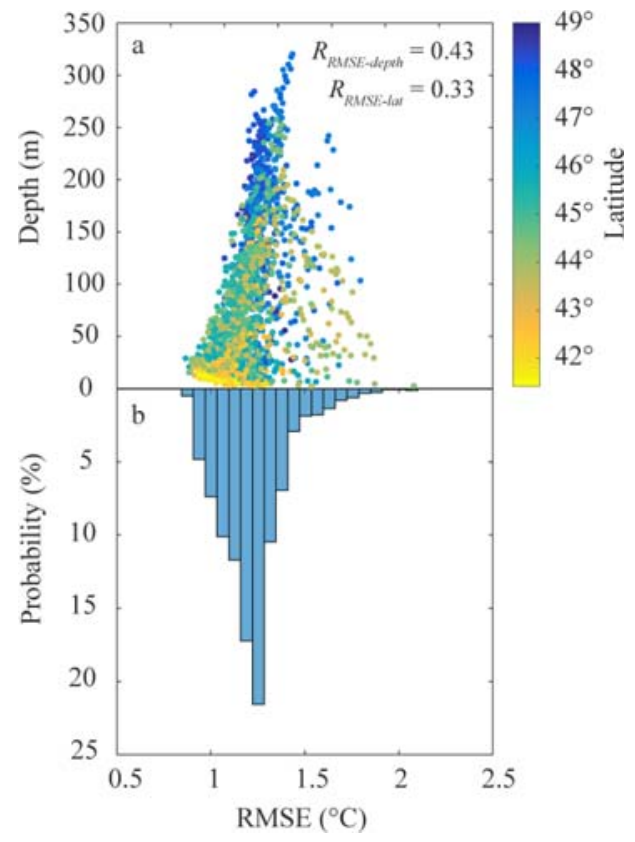

Figure 4. (a) Root mean squared error (RMSE) between the daily simulated and observed LSWT relative to the calibration period (time-averaged values) as a function of local water depth and latitude, together with relative Pearson correlation coefficients (R; $p$-values always < 0.05). (b) Probability distribution of RMSE.

\section{Results}

\section{Model performance and parameters distribution}

As a first analysis of the air2water model performances, we compared the simulated and observed LSWT time series during 1995-2018. We report the spatial distribution of daily RMSE and mean error for the simulated LSWT of the 5 lakes during calibration (Fig. 3a and c) and validation (Fig. $3 b$ and $d$ ). The spatial variability of the daily RMSE for the calibration period ranged between 0.8 and $2.1{ }^{\circ} \mathrm{C}$, the mean RMSE across the lakes' cells being equal to $1.2{ }^{\circ} \mathrm{C}$. In validation, the mean RMSE had essentially the same value as in calibration, and the spatial pattern of the RMSE maps during calibration and validation were similar. The daily ME was always small (never above an absolute value of $0.15{ }^{\circ} \mathrm{C}$ ), and its spatial variability ranged between -0.15 and $0.13^{\circ} \mathrm{C}$ (Fig. $3 \mathrm{C}$ and d). During the calibration period, the ME was overall positive but had a negative value along the western coast of almost all lakes.

The monthly lake average RMSE (Supplemental Table S1) ranged overall between 0.5 and $2.0^{\circ} \mathrm{C}$, with smaller values in winter (when the variability of the LSWT was reduced) and larger values at the beginning of the stratified period (when the LSWT increased rapidly). By contrast, ME showed no clear seasonal pattern (Supplemental Table S1), with small positive and negative biases alternating for all lakes and investigated periods.

In both the calibration and validation periods, the spatial distribution of the mean RMSE showed no strong correlation with the bathymetry or with latitude (see Fig. 4 for the calibration period, with Pearson correlation coefficients 0.43 and 0.33 , respectively; $p$-value 

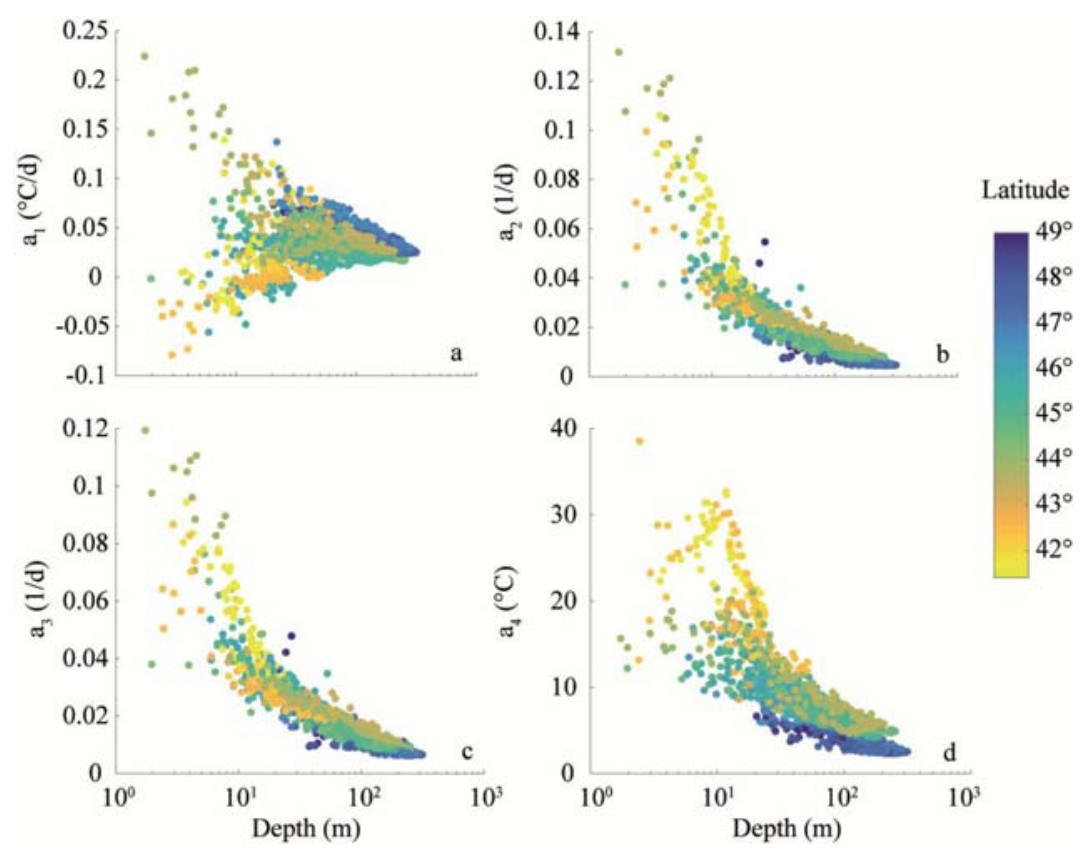

Figure 5. Dependence of air2water model parameters on latitude and depth.

$<0.05$ in both cases). This finding indicates that the accuracy of air2water model is not strongly affected by the geographical location and lake morphology, and that the model is equally able to simulate reliably LSWT for shallow, deep, and very deep cells. Note that the accuracy does not significantly depend on whether the AT forcing is lake-averaged or its intralake spatial distribution is maintained (discussed earlier; see Supplemental Fig. S2 and S3 for corresponding figures for intra-lake distribution).

The distribution of the parameters $a_{2}, a_{3}$, and $a_{4}$ of the air2water model showed a clear dependency on depth (Fig. 5), as suggested in Toffolon et al. (2014): the shallower the lake cell, the higher the parameter value. Moreover, parameter $a_{4}$ also had a clear latitudinal pattern: given the same depth, $a_{4}$ values decreased with higher latitudes. Parameter $a_{1}$ showed no clear dependency on depth and latitude, being more scattered than the other parameters, although its variability decreased with depth.

\section{Warmer scenario and depth-latitude dependency}

The LSWT response to the warmer AT synthetic scenario showed significant intra- and inter-lake variability. We report the monthly averaged temperature difference (LSWT warming, $\Delta \mathrm{T}$ ) for cells belonging to the different bathymetric classes (shallow, deep, and very deep) and for each lake (Fig. 6), together with the monthly averaged AT climatological year. For all lakes, the monthly LSWT warming was not constant throughout the year, despite the uniform increase of AT $\left(2{ }^{\circ} \mathrm{C}\right)$ used to build the synthetic warming scenario. Specifically, the LSWT warming was less than $\mathrm{AT}$ warming $\left(\Delta \mathrm{T}<2{ }^{\circ} \mathrm{C}\right)$ in cold months and greater $\left(\Delta \mathrm{T}>2{ }^{\circ} \mathrm{C}\right)$ in warm months, although with some differences among the 5 lakes. In addition, the 3 different bathymetric classes responded differently in both timing and magnitude to the same increase in AT. The warming peak of shallow cells occurred earlier (between May and June, depending on the lake) than for the other 2 bathymetric classes in all lakes, and in all cases the maximum LSWT warming was observed for the very deep cells between June and July. Additionally, Lake Superior had the highest maximum monthly anomaly among all the lakes.

The maximum daily LSWT warming $(\max \Delta \mathrm{T})$ and the DOY when this maximum occurred in the 5 lakes were heterogeneous (Fig. $7 \mathrm{a}$ and $\mathrm{b}$ ). The maximum $\Delta \mathrm{T}$ ranged between 2.2 and $5.9^{\circ} \mathrm{C}$, and its spatial variability showed a pattern similar to that of bathymetry (Fig. 1): higher $\max \Delta \mathrm{T}$ in the deepest parts of the lakes and lower max $\Delta \mathrm{T}$ toward the coastal shallower zones. The timing of the maximum warming was affected by both depth and latitude, with a later occurrence observed for deep and higher latitude cells.

Finally, we analysed the difference of duration of summer stratification ( $\triangle$ DSS; i.e., stratification lengthening) and the maximum daily LSWT warming ( $\max \Delta \mathrm{T}$ discussed earlier) between the warmer and the actual scenario for each cell of all lakes, looking at their dependence on local depth and latitude (Fig. 8). The DSS lengthened in the warmer scenario for all cells in all 

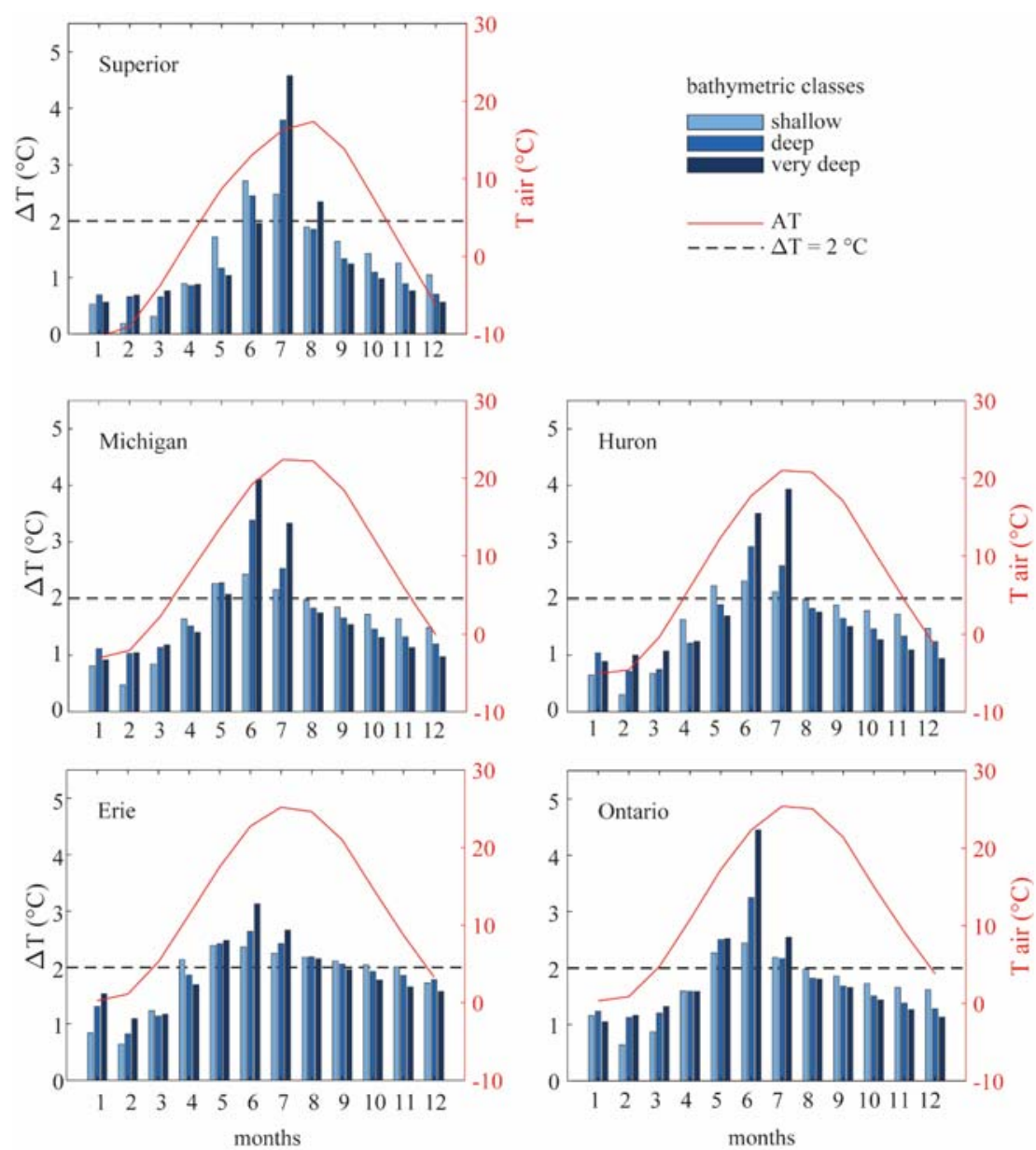

Figure 6. Monthly warming $(\Delta \mathrm{T})$ of LSWT under the synthetic warmer scenario calculated as the difference between the monthly averaged LSWT under the synthetic warmer scenario and under the actual scenario for 1995-2018. Shallow, deep, and very deep classes are reported in different colours to better differentiate their warming. The solid red line shows the climatological year of the actual air temperature over each lake. A dashed line is drawn at $\Delta \mathrm{T}=2{ }^{\circ} \mathrm{C}$ to indicate the uniform air temperature warming scenario considered in the analysis.

lakes, with a stronger effect for lower latitudes and deeper zones (Fig. 8a and b). Similarly, max $\Delta$ T was always positive and essentially dependent on the depth, with no evident influence of latitude (Fig. 8c) or DSS (Fig. 8d).

\section{Discussion}

\section{Insights from the spatial distribution of model performance}

The first research questions we raised concerned the ability of a model like air2water to accurately reproduce the intra-lake heterogeneity of LSWT. The results show that the model performs well and is able to implicitly "downscale" the uniform lake-averaged AT used as input for each computational cell, with overall model performance fully comparable to assuming a spatial varying AT distribution (see Supplemental Fig. S2). The overall pattern of the RMSE and ME is, indeed, similar in the simulations using the uniform lakeaveraged $\mathrm{AT}$ and in those using the spatially varying AT, meaning that any visible pattern cannot be considered an artefact of the use of the lake-averaged AT.

Note that although the overall accuracy of the model is high, some cells of the lake present relatively higher RMSE values $\left(>2{ }^{\circ} \mathrm{C}\right)$. These few cells are located on the western coast of Lake Superior and of Lake Ontario, and, to a lesser extent, on the southwest of Lake Huron (Fig. 3a and b). Here, the simulated LSWT is overall cooler than the observed LSWT, especially during the calibration period $(\mathrm{ME}<0$ in Fig. $3 \mathrm{c}$ and Supplemental Fig. S2 in the case of spatially varying AT). These zones correspond to regions where heat transport processes are dominant, such as upwelling of deep water (Bennington et al. 2010, Wells and Parker 2010, Wang et al. 2015), but are not included in the model formulation we adopted. In fact, air2water is a lumped model that, although applied in a spatially 


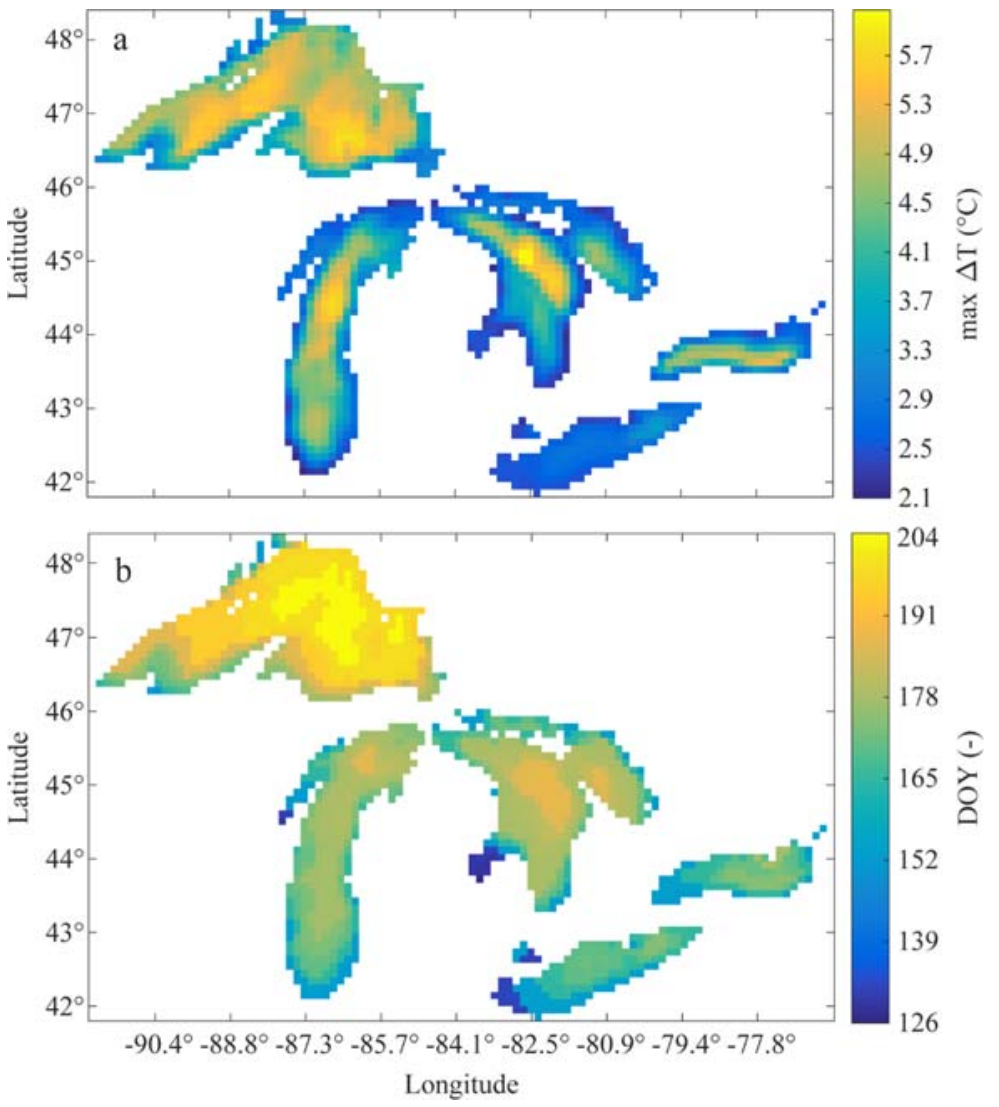

Figure 7. Maximum daily LSWT increment $(\max \Delta \mathrm{T})$ between the (a) actual and warmer AT scenarios and (b) day of the year (DOY) when these increments occur.

distributed manner, solves neither the lateral exchanges between adjacent water columns nor the vertical fluxes from/to the deep water. Therefore, in the regions where horizontal and/or vertical transport processes are important, the model is expected to be less accurate in reproducing the observed LSWT. The localization of the highest values of RMSE (Fig. 2) is coherent with the results by Mason et al. (2016) who showed that consistent patterns of upwelling of colder water, which in the Laurentian Great Lakes are usually wind-driven phenomena, occur along the western coasts because of prevailing winds from southwest to northeast (Bennington et al. 2010, Wang et al. 2015). Also, satellite thermal images showed that the occurrence of wind-driven currents in the western coasts of the Laurentian Great Lakes (Plattner et al. 2009) and other wave-like processes can contribute to lateral or vertical hydrodynamic processes, with potential effects on LSWT (Csanady 1981, Beletsky et al. 1999).

Apart from such specific zones, the relatively homogeneous spatial distribution of RMSE indicates that LSWT inter-lake and intra-lake variability depends essentially on the 2 factors explicitly included in the air2water model: the stratification dynamics and the effect of AT, with the latter playing a role only for the inter-lake variability because AT is assumed uniform lakewide. The strong dependence of LSWT on AT was highlighted by previous studies (e.g., Austin and Allen 2011), which also showed that AT is the leading driver of summertime lake warming. We stress that, although the role of stratification on LSWT was also discussed previously (Imboden and Wüest 1995, Wetzel 2001), its inclusion in a simple lumped model like air2water is a necessary ingredient to obtain realistic results (e.g., Piccolroaz et al. 2015).

\section{Spatial and temporal variability of LSWT response to a warming scenario}

The second research question concerned the variability of the response to a constant and uniform warming of AT. Our results showed that the LSWT variations had a similar warming cycle for all lakes and for all 3 bathymetric classes: an increasing phase in spring, a maximum in summer, and a decreasing phase in fall. This seasonal variability resembles the warming pattern observed in other lakes, from the largest one on Earth (Lake Baikal; e.g., Piccolroaz and Toffolon 2018) to medium-sized lakes (with varying lake area and depth; e.g., Czernecki and Ptak 2018) and reinforces previous 

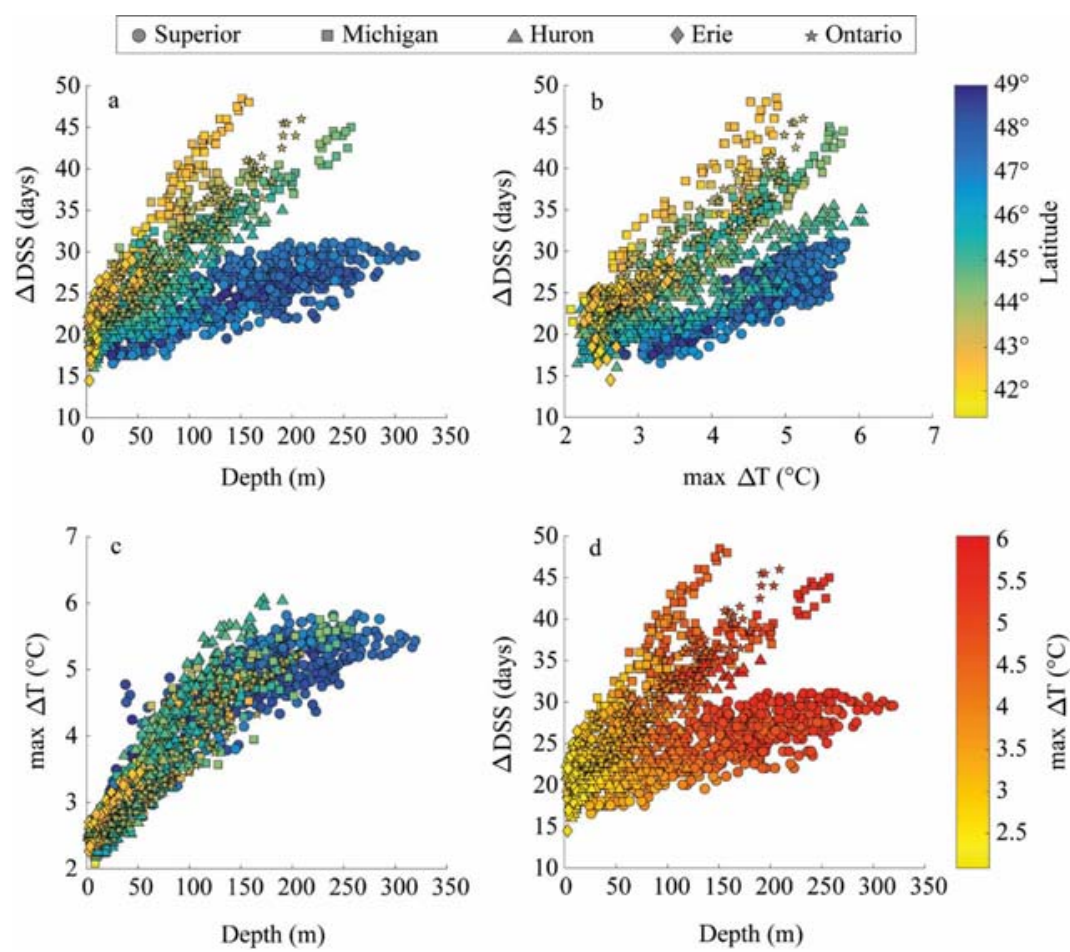

Figure 8. Relationships among stratification lengthening ( $\triangle \mathrm{DSS}$ ) and maximum LSWT (max $\Delta T$ ) between actual and warmer AT scenarios, depth, and latitude: (a) $\Delta \mathrm{DSS}$ as a function of depth and of (b) max $\Delta T$ for different latitudes; (c) max $\Delta T$ as a function of depth for different latitudes; (d) $\Delta \mathrm{DSS}$ as a function of depth for different max $\Delta \mathrm{T}$. Different symbols represent cells belonging to different lakes as specified in the legend. Top colour bar refers to panels (a), (b), and (c) and the bottom colour bar to panel (d).

studies indicating that LSWT warming can be characterized by significant seasonality (Winslow et al. 2017, Woolway et al. 2017).

The intra-lake differences in warming response strongly depend on the bathymetry of the lake and on the stratification dynamics, with the latter factor explaining the dependence on the period of the year (Fig. 6). The peak of monthly $\Delta \mathrm{T}$ was tightly connected with the change (i.e., anticipation) in the timing of thermal stratification resulting from considering a warmer scenario. In fact, an increase in the external AT established a positive feedback between LSWT warming and earlier onset of thermal stratification, which in turn was controlled by the local bathymetry (Piccolroaz et al. 2015). We describe the dynamics in detail considering different periods.

When the lakes are ice-free and not stratified (e.g., in spring), the water column is nearly well mixed and the absorbed heat from the atmosphere is distributed over the whole lake volume. Shallow cells, characterized by a smaller water volume per unit of surface area, have lower thermal inertia in responding to AT warming and thus rapidly adapt to changes in AT. By contrast, very deep cells are characterized by a much larger volume and thus larger thermal inertia, which makes them less prone to change in AT during this phase. As a consequence, shallow cells experience the maximum LSWT warming in May-June, earlier than the other cell classes. The maximum LSWT warming of very deep cells instead occurs later in the year (Jun-Jul) when they start to stratify. Recent studies observed that the deep areas of larger lakes experience a later onset of thermal stratification (Woolway and Merchant 2018, Fichot et al. 2019). Deep cells represent an intermediate case between the examples described above. The agreement of such dynamics with the results of the recent data-driven analysis of Toffolon et al. (2020) demonstrates the reliability of the distributed application of air2water model.

The LSWT warming of very deep cells is significantly amplified compared to the corresponding AT warming $\left(\Delta \mathrm{T}>2{ }^{\circ} \mathrm{C}\right)$. This amplification effect observed in previous studies that focused on the summer period of JulyAugust-September (Austin and Colman 2007, Schneider and Hook 2010, Piccolroaz et al. 2015, Woolway and Merchant 2017) is linked to a positive feedback between surface warming and stratification. This effect is particularly important for the deep zones, where in stratified conditions the well-mixed surface layer is much shallower than the whole water column. Under these conditions, the water volume responding to AT variations is relatively small, and an anticipation of 
such stratification conditions under the warming scenario results in a faster increase of LSWT, which further increases thermal stratification, generating a positive feedback loop (Piccolroaz et al. 2015, Zhong et al. 2016, Woolway and Merchant 2017).

The previously mentioned warming-stratification feedback is also a key factor explaining the inter-lake warming variability, in terms of both timing and intensity. Our results show that the annual maxima of LSWT warming $(\max \Delta \mathrm{T})$ are not the same among the 5 lakes (Fig. 6). Lake Superior is the deepest of the Laurentian Great Lakes and hence has the highest LSWT warming among all the lakes (up to $4.6{ }^{\circ} \mathrm{C}$ in July for very deep cells, on the monthly time scale), while Lake Erie has the smallest maximum warming $\left(\sim 3.1{ }^{\circ} \mathrm{C}\right.$ in June for very deep cells). In addition, Lake Erie is characterized by little variability in timing and magnitude of the warming among the 3 bathymetric classes (Fig. 6) because of the limited variability of its bathymetry (Table 1). The other lakes, and particularly Lake Superior, are characterized by a wider range of depths and hence larger variability in LSWT response among the bathymetric classes. Indeed, the slower overturning progress occurring in larger and/or deeper lakes together with the possible formation of thermal bars (slow-moving $4{ }^{\circ} \mathrm{C}$ thermal fronts that can occur in lakes with higher bathymetric variability and especially in zones with steep bottom slope) enhances the heterogeneity in the lake thermal response (Fichot et al. 2019).

To summarize, the variability of LSWT response to warming is clearly visible both for lakes with different average depths (inter-lake variability) and for zones of the same lake with different local depths (intra-lake variability). In this respect, a simple synthetic warming scenario can profitably be used to identify periods and regions where an enhanced LSWT warming response is expected.

\section{The combined role of depth and latitude}

Our third research question concerned examining the combined effects of depth and latitude on the warming dynamics. The higher maximum $\Delta \mathrm{T}$ in the deepest regions of the lakes and the lower maximum $\Delta \mathrm{T}$ toward the coastal shallower zones (Fig. 8c) support the crucial role of bathymetry in controlling the warming dynamics, discussed earlier. This warming pattern is consistent with that observed in the last decades (Mason et al. 2016, Woolway and Merchant 2018, Zhong et al. 2019), and results are coherent with projections obtained with a 3-dimensional hydrodynamic model for Lake Superior (Matsumoto et al. 2019). The timing of LSWT warming is described by the DOY map (Fig. 7b). Overall, the max
$\Delta \mathrm{T}$ occurs between May and July, but later for higher than for lower latitudes. This delay can be explained by 2 different factors. First, higher latitudes have a shifted AT cycle, with AT peaking later than at lower latitudes (Fig. 6), thus delaying the spring overturn (Fichot et al. 2019) and stratified conditions; consequently, the warming-stratification feedback occurs later in the year. Second, Lake Superior is at high latitudes and is much deeper than the other Laurentian Great Lakes, thus further delaying stratification because of the larger thermal inertia. These results demonstrate that both bathymetry and latitude can exert a major control on shaping LSWT dynamics because of their strong control on lake overturning and stratification timing (Fichot et al. 2019)

This dual dependency is also confirmed by the distribution of the model parameters with depth and latitude (Fig. 5). The smaller values of $a_{2}$ and $a_{3}$ in the deeper zones indicate lower correlation and slow adaptation of LSWT to AT changes because of the high thermal inertia of the water column. Moreover, the smaller values of $a_{4}$ in the deeper zones indicate larger seasonal variability of the thickness of the well-mixed surface layer participating in the heat exchange with the atmosphere, and hence a larger effect of thermal stratification on controlling LSWT throughout the year (Toffolon et al. 2014, Piccolroaz 2016). A dependency of $a_{4}$ on latitude can also be appreciated, with the parameter assuming smaller values and its variability decreasing (especially for shallower zones) with increasing latitude (Supplemental Fig. S4), suggesting that lake zones with the same depth but located at higher latitudes behave like the deeper ones. Finally, the parameter $a_{1}$ shows a clear scatter for shallower zones while its variability decreases for larger depths. Note that although this parameter summarizes all residual effects, its distribution suggests that while LSWT of deep regions is essentially controlled by AT, lake thermal inertia, and stratification, other processes in shallower areas may become important, such as horizontal/vertical transport of heat, larger scale circulation, and heat flux from/to the bottom, among others. This hypothesis is consistent with larger RMSE and ME observed in the shallow western areas of some lakes (Fig. 3) that are attributable to the effect of water transport processes that redistribute heat (as noted earlier).

For a deeper consideration of the factors affecting the dual dependency of lake thermal response on depth and latitude, refer to the scatter plot (Fig. 8a) illustrating how $\triangle$ DSS depends on depth (horizontal axis) and latitude (marker colour). $\triangle \mathrm{DSS}$ is always positive and ranges between 16 and 49 days, indicating that the stratification period lengthens under a warmer AT scenario, but this lengthening varies among and within lakes because of 
the control exerted by local depth and latitude. In general, $\triangle \mathrm{DSS}$ is longer at greater depths, an effect attenuated by higher latitudes (lower AT). Thus, the warming of AT has a greater effect on stratification of deeper lake zones, but at higher latitudes the lengthening is less visible than at lower latitudes. In addition, the maximum LSWT warming $(\max \Delta \mathrm{T})$ is positively correlated with the stratification lengthening (Fig. 8b). Particularly, max $\Delta \mathrm{T}$ seems to increase more with the lengthening of stratification at higher latitudes. However, this trend is only apparent because of the dependence of $\triangle \mathrm{DSS}$ on latitude and the uneven distribution of depth with latitude, whereby deeper zones are more abundant at higher latitudes (Fig. 1a). Indeed, a more careful analysis shows that max $\Delta \mathrm{T}$ essentially depends on the local depth (Fig. 8c), almost irrespective of the latitude. Such a relationship is also confirmed by the absence of a clear pattern of max $\Delta \mathrm{T}$ on the relation between stratification lengthening and depth (Fig. 8d: note the use of different symbols for different lakes in subplots to dispel any doubt that the patterns discussed above are lake specific).

As a whole, depth strongly regulates the timing and magnitude of the accelerated warming for the Laurentian Great Lakes, as also observed by Zhong et al. $(2016,2019)$. Latitude is also a control on lake thermal warming through its effect on the timing and duration of thermal stratification; however, it does not have an evident effect on the magnitude of max $\Delta \mathrm{T}$, only on the period of the year when it occurs. In this regard, our results help to disentangle the separate effects of latitude and depth on both intra-lake and inter-lake LSWT variability.

\section{Approach limitations and outlook}

We demonstrated that, despite its simplicity, the air2water model can reproduce the spatial distribution of LSWT when applied in a distributed manner. However, the limitations of this approach cannot be neglected. First, because the hydrodynamics of the lakes are not considered, the model is unable to reproduce the LSWT when water transport processes of heat are the main driver of the LSWT (see the large RMSE in some coastal regions in Fig. 3). Second, because AT is the only forcing in the model, the effect of other meteorological variables or water quality conditions is not explicitly considered, including the role of wind speed or light attenuation in affecting lake stratification. We also acknowledge that a physically based ice module is not included in the currently available version of the air2water model. While this lack may possibly affect the performance of the model in precisely simulating the ice cover timing, the current version of the model showed overall good performance when applied to lakes that freeze in winter (e.g., Toffolon et al. 2014, Piccolroaz et al. 2015, Czernecki and Ptak 2018, Piccolroaz and Toffolon 2018, Flaim et al. 2020). Finally, the results from the synthetic warmer scenario should not be read as future projections, but rather as a test to evaluate the response of different lake zones to a warming climate.

Given the ability of the air2water model to reproduce the intra-lake and inter-lake heterogeneity of LSWT, further applications using more realistic scenarios would be interesting. Indeed, with a small computational cost, even when applied in a distributed manner, air2water could be applied with reference to an ensemble of future climate scenarios and thus provide an evaluation of the uncertainty of the LSWT projections in the lakes under investigation. Finally, the reasonable values of LSWT reproduced using a lake-averaged AT time series for each lake as input makes this methodology suitable for data-scarce contexts where the application of process-based models is prevented by the lack of complete and accurate meteorological information.

\section{Conclusions}

Pronounced AT warming is projected for the rest of the century across the Laurentian Great Lakes region (Notaro et al. 2015); therefore, it is important to develop tools that reliably predict the spatial and temporal variability of LSWT dynamics. In this study, we examined the spatially distributed application of the hybrid air2water model in the 5 Laurentian Great Lakes, demonstrating it was able to adequately simulate the intraand inter-lake heterogeneity of LSWT. Although such a simple conceptualization cannot capture all the processes governing the thermal dynamics in a large lake, our results suggest that this simplified approach might represent an alternative to process-based 3-dimensional hydrodynamic models commonly used to predict the spatial distribution of LSWT in lakes. Our finding is particularly important in those contexts where lack of data or large errors may jeopardize the accuracy of more complex physically based models. Moreover, our results show that using a simple model, which does not solve the full lake hydrodynamics, could be useful to identify regions where LSWT is driven not only by the atmospheric heat exchange but also by the vertical and lateral fluxes (e.g., heat transport processes such as upwelling). Knowing where such processes occur is extremely useful for lake managers.

The same model was applied to a simple synthetic warmer scenario to identify regions of the Laurentian Great Lakes that are more sensitive to LSWT variation due climatic changes. The shallow zones of the 5 lakes 
responded earlier than other parts of the lake to the AT warming and are expected to warm less compared to the deep and very deep zones. Very deep cells experience the greatest warming in all 5 lakes during the summer months, which is related to the setup of stratification. Moreover, based on our findings, even if the duration of summer stratification increases significantly both in the deep regions and in low latitudes zones, the warming effect is essentially correlated with the local depth.

Our study highlights the possibility to adopt an alternative approach to complex, fully deterministic lake models to study and predict the heterogeneous response of LSWT warming to changes in climatic conditions. At the same time, it cautions using lake-averaged LSWT in climate change impact studies, which could lead to an oversimplification of the representation of the spatial heterogeneity of lake thermal response, as noted by Toffolon et al. (2020) by analysing the available data.

\section{Acknowledgements}

The authors are grateful to NOAA (National Oceanic and Atmospheric Administration) which provided LSWT data used in this work (data can be downloaded from http://www. glerl.noaa.gov) as well as to ECMWF (European Centre for Medium-Range Weather Forecasts) for providing air temperature reanalysis (data can be downloaded from https://www. ecmwf.int/). This research has been supported by the Italian Ministry of Education, University and Research (MIUR) under the Departments of Excellence, grant L.232/2016. The source codes of the air2water model is freely available at the following link: https:/github.com/spiccolroaz/air2water.

\section{Disclosure statement}

No potential conflict of interest was reported by the author(s).

\section{ORCID}

Elisa Calamita (D http://orcid.org/0000-0002-2614-2942 Sebastiano Piccolroaz (D) http://orcid.org/0000-0003-17967624

Bruno Majone (D) http://orcid.org/0000-0003-3471-7408

Marco Toffolon (D) http://orcid.org/0000-0001-6825-7070

\section{References}

Adrian R, O’Reilly CM, Zagarese H, Baines SB, Hessen DO, Keller W, Livingstone DM, Sommaruga R, Straile D, Van Donk E, et al. 2009. Lakes as sentinels of climate change. Limnol Oceanogr. 54(6 Pt 2):2283-2297.

Austin JA, Allen J. 2011. Sensitivity of summer Lake Superior thermal structure to meteorological forcing. Limnol Oceanogr. 56(3):1141-1154.

Austin JA, Colman SM. 2007. Lake Superior summer water temperatures are increasing more rapidly than regional air temperatures: a positive ice-albedo feedback. Geophys Res Lett. 34(6):L06604.

Beaulieu M, Pick F, Gregory-Eaves I. 2013. Nutrients and water temperature are significant predictors of cyanobacterial biomass in a 1147 lakes data set. Limnol Oceanogr. 58 (5):1736-1746.

Beletsky D, Saylor JHJ, Schwab DJ. 1999. Mean circulation in the Great Lakes. J Great Lakes Res. 25(1):78-93.

Bennington V, McKinley GA, Kimura N, Wu CH. 2010. General circulation of Lake Superior: mean, variability, and trends from 1979 to 2006. J Geophys Res. 115(C12): C12015.

Binding CE, Greenberg TA, McCullough G, Watson SB, Page E. 2018. An analysis of satellite-derived chlorophyll and algal bloom indices on Lake Winnipeg. J Great Lakes Res. 44(3):436-446.

Bouffard D, Kiefer I, Wüest A, Wunderle S, Odermatt D. 2018. Are surface temperature and chlorophyll in a large deep lake related? An analysis based on satellite observations in synergy with hydrodynamic modelling and insitu data. Remote Sens Environ. 209:510-523.

Boyce FMM, Donelan MAA, Hamblin PFF, Murthy CRR, Simons TJJ. 1989. Thermal structure and circulation in the Great Lakes. Atmos Ocean. 27(4):607-642.

Butcher JB, Nover D, Johnson TE, Clark CM. 2015. Sensitivity of lake thermal and mixing dynamics to climate change. Clim Change. 129(1-2):295-305.

Carmack EC, Vagle S, Morrison J, Laval BE. 2014. Space-fortime proxy for climate change in deep lakes in the Canadian Cordillera: seasonality along a latitudinal climate gradient. J Great Lakes Res. 40(3):608-617.

Csanady GT. 1981. Circulation in the coastal ocean. Adv Geophys. 23:101-183.

Czernecki B, Ptak M. 2018. The impact of global warming on lake surface water temperature in Poland - the application of empirical-statistical downscaling, 1971-2100. J Limnol. 77(2):330-348.

Fichot CG, Matsumoto K, Holt B, Gierach MM, Tokos KS. 2019. Assessing change in the overturning behavior of the Laurentian Great Lakes using remotely sensed lake surface water temperatures. Remote Sens Environ. 235:111427.

Flaim G, Andreis D, Piccolroaz S, Obertegger U. 2020. Ice cover and extreme events determine dissolved oxygen in a placid mountain lake. Water Resour Res. 56(9):1-18.

Gerbush MR, Kristovich DAR, Laird NF. 2008. Mesoscale boundary layer and heat flux variations over pack ice-covered Lake Erie. J Appl Meteorol Climatol. 47(2):668-682.

Giardino C, Bresciani M, Stroppiana D, Oggioni A, Morabito G. 2013. Optical remote sensing of lakes: an overview on Lake Maggiore. J Limnol. 73(s1).

Gorham E, Boyce FM. 1989. Influence of lake surface area and depth upon thermal stratification and the depth of the summer thermocline. J Great Lakes Res. 15(2):233-245.

Griffiths DV, Smith IM. 2006. Numerical methods for engineers. Boca Raton (FL, USA): Chapman and Hall/CRC.

Heddam S, Ptak M, Zhu S. 2020. Modelling of daily lake surface water temperature from air temperature: extremely randomized trees (ERT) versus Air2Water, MARS, M5Tree, RF and MLPNN. J Hydrol. 588(June):125-130.

Hunter TS, Clites AH, Campbell KB, Gronewold AD. 2015. Development and application of a North American Great Lakes hydrometeorological database - part I: precipitation, 
evaporation, runoff, and air temperature. J Great Lakes Res. 41(1):65-77.

Hutchinson GE, Loffler H. 1956. The thermal classification of lakes. P Natl Acad Sci USA. 42(2):84-86.

Imboden DM, Wüest A. 1995. Mixing mechanisms in lakes. Chapter 4. In: Lerman A, Imboden DM, Gat JR, editors. Physics and chemistry of lakes. Cham (Switzerland): Springer; p. 83-138.

Irani Rahaghi A, Lemmin U, Sage D, Barry DA. 2019. Achieving high-resolution thermal imagery in low-contrast lake surface waters by aerial remote sensing and image registration. Remote Sens Environ. 221:773-783.

Javaheri A, Babbar-Sebens M, Miller RN. 2016. From skin to bulk: an adjustment technique for assimilation of satellite-derived temperature observations in numerical models of small inland water bodies. Adv Water Resour. 92:284-298.

Kennedy J, Eberhart R, Gov B. 2010. Particle swarm optimization. In: Sammut C, Webb GI, editors. Encyclopedia of machine learning and data mining. Boston (MA, USA): Springer; p. 760-766.

Kraemer BM, Anneville O, Chandra S, Dix M, Kuusisto E, Livingstone DM, Rimmer A, Schladow SG, Silow E, Sitoki LM, et al. 2015. Morphometry and average temperature affect lake stratification responses to climate change. Geophys Res Lett. 42(12):4981-4988.

Kravtsov S, Sugiyama N, Roebber P. 2018. Role of nonlinear dynamics in accelerated warming of Great Lakes. In: Tsonis AA, editor. Advanced Nonlinear Geoscience. Cham (Switzerland): Springer International Publishing; p. 279-295.

Leshkevich G, Schwab D, Muhr G. 1996. Satellite environmental monitoring of the Great Lakes: Great Lakes Coastwatch program update. Mar Technol Soc. 30(4):28-35.

Lieberherr G, Wunderle S. 2018. Lake Surface water temperature derived from 35 years of AVHRR sensor data for European lakes. Remote Sens. 10(7):990.

Magee MR, Wu CH. 2017. Response of water temperatures and stratification to changing climate in three lakes with different morphometry. Hydrol Earth Syst Sci. 21(12):6253-6274.

Mason LA, Riseng CM, Gronewold AD, Rutherford ES, Wang J, Clites A, Smith SDP, McIntyre PB. 2016. Fine-scale spatial variation in ice cover and surface temperature trends across the surface of the Laurentian Great Lakes. Clim Change. 138(1-2):71-83.

Matsumoto K, Tokos KS, Rippke J. 2019. Climate projection of Lake Superior under a future warming scenario. J Limnol. 78(3):296-309.

McCormick MJ. 1990. Potential changes in thermal structure and cycle of Lake Michigan due to global warming. T Am Fish Soc. 119(2):183-194.

Notaro M, Bennington V, Vavrus S. 2015. Dynamically downscaled projections of lake-effect snow in the Great Lakes Basin. J Clim. 28(4):1661-1684.

Oesch D, Jaquet J-M, Klaus R, Schenker P. 2008. Multi-scale thermal pattern monitoring of a large lake (Lake Geneva) using a multi-sensor approach. Int J Remote Sens. 29 (20):5785-5808.

O’Reilly CM, Sharma S, Gray DK, Hampton SE, Read JS, Rowley RJ, Schneider P, Lenters JD, McIntyre PB, Kraemer BM, et al. 2015. Rapid and highly variable warming of lake surface waters around the globe. Geophys Res Lett. 42(24):10773-10781.

Pareeth S, Salmaso N, Adrian R, Neteler M. 2016. Homogenised daily lake surface water temperature data generated from multiple satellite sensors: a long-term case study of a large sub-Alpine lake. Sci Rep. 6(1):31251.

Piccolroaz S. 2016. Prediction of lake surface temperature using the air2water model: guidelines, challenges, and future perspectives. Adv Oceanogr Limnol. 7(1):36-50.

Piccolroaz S, Healey NC, Lenters JD, Schladow SG, Hook SJ, Sahoo GB, Toffolon M. 2018. On the predictability of lake surface temperature using air temperature in a changing climate: a case study for Lake Tahoe (U.S.A.). Limnol Oceanogr. 63(1):243-261.

Piccolroaz S, Toffolon M, Majone B. 2013. A simple lumped model to convert air temperature into surface water temperature in lakes. Hydrol Earth Syst Sci. 17(8):3323-3338.

Piccolroaz S, Toffolon M, Majone B. 2015. The role of stratification on lakes' thermal response: the case of Lake Superior. Water Resour Res. 51(10):7878-7894.

Piccolroaz S, Toffolon M. 2018. The fate of Lake Baikal: how climate change may alter deep ventilation in the largest lake on Earth. Clim Change. 150(3-4):181-194.

Piccolroaz S, Woolway RI, Merchant CJ. 2020. Global reconstruction of twentieth century lake surface water temperature reveals different warming trends depending on the climatic zone. Clim Change. 160:427-442.

Plattner S, Mason DM, Leshkevich GA, Schwab DJ, Rutherford ES. 2009. Classifying and forecasting coastal upwellings in Lake Michigan using satellite derived temperature images and buoy data. J Great Lakes Res. 32(1):63-76.

Prats J, Danis P-A. 2019. An epilimnion and hypolimnion temperature model based on air temperature and lake characteristics. Knowl Manag Aquat Ecosyst. 420:8.

Prats J, Reynaud N, Rebière D, Peroux T, Tormos T, Danis PA. 2018. LakeSST: lake skin surface temperature in French inland water bodies for 1999-2016 from Landsat archives. Earth Syst Sci Data. 10(2):727-743.

Schmid M, Köster O. 2016. Excess warming of a Central European lake driven by solar brightening. Water Resour Res. 52(10):8103-8116.

Schneider P, Hook SJ, Radocinski RG, Corlett GK, Hulley GC, Schladow SG, Steissberg TE. 2009. Satellite observations indicate rapid warming trend for lakes in California and Nevada. Geophys Res Lett. 36(22):1-6.

Schneider P, Hook SJ. 2010. Space observations of inland water bodies show rapid surface warming since 1985 . Geophys Res Lett. 37(22):1-5.

Schwab DJ, Leshkevich GA, Muhr GC. 1999. Automated mapping of surface water temperature in the great lakes. J Great Lakes Res. 25(3):468-481.

Steissberg TE, Hook SJ, Schladow SG. 2005. Characterizing partial upwellings and surface circulation at Lake Tahoe, California-Nevada, USA with thermal infrared images. Remote Sens Environ. 99(1-2):2-15.

Stepanenko VM, Goyette S, Martynov A, Perroud M, Fang X, Mironov D. 2010. First steps of a lake model intercomparison project: LakeMIP. Boreal Environ Res. 15(2):191-202.

Sugiyama N, Kravtsov S, Roebber P. 2018. Multiple climate regimes in an idealized lake-ice-atmosphere model. Clim Dyn. 50(1-2):655-676. 
Thiery W, Stepanenko VM, Fang X, Jöhnk KD, Li Z, Martynov A, Perroud M, Subin ZM, Darchambeau F, Mironov D, Van Lipzig NPM. 2014. LakeMIP Kivu: evaluating the representation of a large, deep tropical lake by a set of one-dimensional lake models. Tellus A. 66(1):1-18.

Toffolon M, Piccolroaz S, Majone B, Soja A-M, Peeters F, Schmid M, Wüest A. 2014. Prediction of surface temperature in lakes with different morphology using air temperature. Limnol Oceanogr. 59(6):2185-2202.

Toffolon M, Piccolroaz S, Calamita E. 2020. On the use of averaged indicators to assess lakes' thermal response to changes in climatic conditions. Environ Res Lett. 15(3):034060.

Trumpickas J, Shuter BJ, Minns CK. 2009. Forecasting impacts of climate change on great lakes surface water temperatures. J Great Lakes Res. 35(3):454-463.

Trumpickas J, Shuter BJ, Minns CK, Cyr H. 2015. Characterizing patterns of nearshore water temperature variation in the North American Great Lakes and assessing sensitivities to climate change. J Great Lakes Res. 41 (1):53-64.

Vašek M, Prchalová M, Ř́ha M, Blabolil P, Čech M, Draštík V, Frouzová J, Jůza T, Kratochvíl M, Muška M, et al. 2016. Fish community response to the longitudinal environmental gradient in Czech deep-valley reservoirs: implications for ecological monitoring and management. Ecol Indic. 63:219-230.

Vavrus SJ, Wynne RH, Foley JA. 1996. Measuring the sensitivity of southern Wisconsin lake ice to climate variations and lake depth using a numerical model. Limnol Oceanogr. 41 (5):822-831.

Wang L, Riseng CM, Mason LA, Wehrly KE, Rutherford ES, McKenna JE, Castiglione C, Johnson LB, Infante DM, Sowa S, et al. 2015. A spatial classification and database for management, research, and policy making: the Great Lakes aquatic habitat framework. J Great Lakes Res. 41 (2):584-596.

Wells M, Parker S. 2010. The thermal variability of the waters of Fathom Five National Marine Park, Lake Huron. J Great Lakes Res. 36(3):570-576.

Wetzel R. 2001. Limnology: lake and river ecosystems. Cambridge (MA, USA): Academic Press.
Wilcox BP. 2010. Transformative ecosystem change and ecohydrology: ushering in a new era for watershed management. Ecohydrology. 3(1):126-130.

Williamson CE, Saros JE, Schindler DW. 2009a. Climate change: sentinels of change. Science. 323(5916):887-888.

Williamson CE, Saros JE, Vincent WF, Smol JP. $2009 \mathrm{~b}$. Lakes and reservoirs as sentinels, integrators, and regulators of climate change. Limnol Oceanogr. 54(6 Pt 2):2273-2282.

Winslow LA, Read JS, Hansen GJA, Rose KC, Robertson DM. 2017. Seasonality of change: summer warming rates do not fully represent effects of climate change on lake temperatures. Limnol Oceanogr. 62(5):2168-2178.

Wood TM, Wherry SA, Piccolroaz S, Girdner SF. 2016. Simulation of deep ventilation in Crater Lake, Oregon, 1951-2099. Reston (VA, USA): US Geological Survey. https://doi.org/10.3133/sir20165046

Woolway RI, Dokulil MT, Marszelewski W, Schmid M, Bouffard D, Merchant CJ. 2017. Warming of Central European lakes and their response to the 1980s climate regime shift. Clim Change. 142(3-4):505-520.

Woolway RI, Merchant CJ. 2017. Amplified surface temperature response of cold, deep lakes to inter-annual air temperature variability. Sci Rep. 7(1):4130.

Woolway RI, Merchant CJ. 2018. Intralake heterogeneity of thermal responses to climate change: a study of large Northern Hemisphere lakes. J Geophys Res Atmos. 123(6):3087-3098.

Ye X, Anderson EJ, Chu PY, Huang C, Xue P. 2019. Impact of water mixing and ice formation on the warming of Lake Superior: a model-guided mechanism study. Limnol Oceanogr. 64(2):558-574.

Zhang G, Yao T, Xie H, Qin J, Ye Q, Dai Y, Guo R. 2014. Estimating surface temperature changes of lakes in the Tibetan Plateau using MODIS LST data. J Geophys Res Atmos. 119(14):8552-8567.

Zhong Y, Notaro M, Vavrus SJ, Foster MJ. 2016. Recent accelerated warming of the Laurentian Great Lakes: physical drivers. Limnol Oceanogr. 61(5):1762-1786.

Zhong Y, Notaro M, Vavrus SJ. 2019. Spatially variable warming of the Laurentian Great Lakes: an interaction of bathymetry and climate. Clim Dyn. 52(9-10):5833-5848.

Zhu S, Ptak M, Yaseen ZM, Dai J, Sivakumar B. 2020. Forecasting surface water temperature in lakes: a comparison of approaches. J Hydrol. 585:124809. 